\title{
RESPONSE OF MAIZE PLANTS TO DIFFERENT N-SOURCES AND FOLIAR APPLICATION OF POTASSIUM HUMATE
}

\author{
Sahar M. Zakaria \\ Soils, Water and Environ. Res., Inst., Agric. Res. Center, Giza, Egypt \\ Received: Jan. 15, 2018 \\ Accepted: Feb. 12, 2018
}

\begin{abstract}
Two field experiments were conducted at El-Kassasin Farm, Ismailia

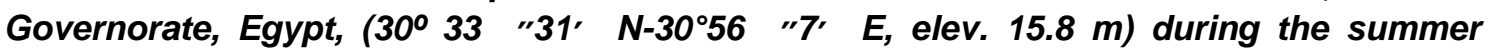
seasons of 2014 and 2015 on maize plants (c.v. single hybrid 30K8) grown on a sandy loam soil to study the effect of applying different sources of $\mathrm{N}$-fertilization alone and in combination with foliar application of humate potassium on yield and its components and quality of maize grains. Different sources of $\mathrm{N}$-fertilization caused significant increases in yield and its components and mineral uptake. Meanwhile, application of 50\% $N$ - mineral as ammonium sulphate $\left(75 \mathrm{~kg} \mathrm{~N} \mathrm{fed.}^{-1}\right)+50 \%$ organic $N\left(75 \mathrm{~kg} \mathrm{~N} \mathrm{fed}^{-1}\right)(5.3 \mathrm{t}$ compost $\mathrm{fed}^{-1}$ ) achieved the highest values of all aforementioned parameters followed by the application of $100 \%$ of the recommended mineral $N$ (150 kg N/fed.) then $100 \%$ organic $N\left(150 \mathrm{~kg} \mathrm{~N} \mathrm{fed.}^{-1}\right)\left(10.6 \mathrm{t}\right.$ compost fed $\left.{ }^{-1}\right)$, in a descending order. Spraying maize plants with potassium humate significantly enhanced plant growth, yield and its components as well as $N, P$ and $K$ uptake, total protein and oil in grains. In this respect, spraying plants with 4 L/fed potassium humate attained the superiority impacts comparing the other treatments. Hence, it can be concluded that fertilizing maize plants with $50 \% \mathrm{~N}$ - mineral $\left(75 \mathrm{~kg} \mathrm{~N} \mathrm{fed}^{-1}\right)+50 \%$ organic $N\left(75 \mathrm{~kg} \mathrm{~N} \mathrm{fed.}^{-1}\right)\left(5.3 \mathrm{t} \mathrm{compost} \mathrm{fed}^{-1}\right)$ in combined with spraying plants at rate 4 L/fed potassium humate gave the highest values of yield and its components and NPK uptake as well as protein and oil content in grains as compared to other interaction treatments.
\end{abstract}

Key words: Grain yield, Maize plants, N-sources, Potassium humate, Protein and oil content

\section{INTRODUCTION}

Maize is called "King of cereals" because of its productivity potential compared to any other cereal crop. Being an exhaustive crop, it has very high nutrients requirement and its productivity is closely depends on nutrient management system. Under the present trend of exhaustive agriculture in Egypt, inherent soil fertility can no longer be maintained on the sustainable basis. It is said that nutrient supplying capacity of soil declines steadily under continuous and intensive cropping system. The optimum levels of $N, P$, and $K$ failed to maintain yield levels probably due to increasing secondary and micronutrient deficiencies and also unfavorable alterations in the physical and chemical properties of soil. Apart from the soil fertility and productivity issues, use of chemical fertilizers is also becoming more and more difficult for the farmers due to their high costs and scarcity during peak season. On thus, increasing awareness is being created on the use of organics which are the sources of macro, micro and secondary nutrients to sustain the soil fertility and productivity.

Mineral nutrition is one of the most important factors for plant growth and yield. Mineral fertilizers, particularly mineral-nitrogen, are important means of plant nutrition; however, they are also a potential source of environmental pollution (Hartman, 1988). An attention has been therefore focused on alternative fertilizers, including organic fertilizers in 
Middle East. Nowadays, there is renewed interest in organic fertilizers for nutrient supply and improve soil fertility and productivity in this region. The integrated use of organic fertilizers and mineral fertilizers is considered the best option not only to reduce the intensive consumption of chemical fertilizers, but also to sustain the soil with minimum undesirable impacts and to maximize fertilizer use efficiency in soil. Organic fertilizers are considered as an ecofriendly way to sustainable agriculture. They positively affect plant growth and yield, reduce the negative effects of chemical fertilizers and minimize some chemicals such as $\mathrm{NO}_{3}{ }^{-}$and $\mathrm{NO}_{2}{ }^{-}$ions in the soil and consequently in plants. Therefore, the way to a healthy agriculture with a minimum pollution requires a conjunctive use of organic nitrogen and mineral-nitrogen fertilizers.

Organic matter also improves water holding capacity of sandy soil and drainage in clayey soil. Organic manure provides nutrients for the soil microorganisms, thus increases the activities of microbes in soil, which in turn help to convert unavailable plant nutrients into available form for plant growth promotion.

Humic acids known as plant growth promoters which can enhance plant yield and quality parameters. Humic substances can enhance seed germination, seedling growth, root growth, overall growth, uptake of macroand micro-elements and the bioavailability of nutrients through amendment of the soil environment at the rhizosphere (Chen and Aviad, 1990; Varanini and Pinton, 1995; Bryan and Stark, 2003 and Mikkelsen, 2005). Humic acid can directly increase the growth of shoots and roots, uptake of nitrogen, potassium, calcium, phosphorus and magnesium by plant through chelating different nutrients to be more available for plants. Humic acid is consistent with nature and is not dangerous for the plant and environment (Haghighi et al. 2011and Abdel Mawgoud et al. 2007).

The objective of the present work was to study the impact of applying different sources of $\mathrm{N}$-fertilization and foliar application of humate potassium on growth, yield and quality of maize.

\section{MATERIALS AND METHODS \\ Field experimental site:}

Two field experiments were conducted at El-Kassasin Farm, Ismailia Governorate, Egypt, $\left(30^{\circ} 33\right.$ " $31^{\prime} \quad \mathrm{N}$ $30^{\circ} 56 " 7$ ' E, elev. $15.8 \mathrm{~m}$ ) during the summer seasons of 2014 and 2015 on maize plants (c.v. single hybrid 30K8) grown on a sandy loam soil to study the effect of applying different sources of $\mathrm{N}$ fertilization and foliar application of humate potassium on growth, yield and yield quality of maize. Randomized soil surface $(0-20 \mathrm{~cm})$ samples were taken from the experimental site before sowing, as well as compost samples to determine the physical and chemical properties according to Klute (1986) and Page et al., (1982) as shown in Tables (1 \& 2).

\section{Experimental treatments:}

Each experiment included nine treatments which were the combinations of the three different nitrogen sources treatments and three treatments of potassium humate. The experimental design was split-plot system in randomized complete blocks with three replications. The main plots were allocated for $\mathrm{N}$ - sources, whereas, the sub-plots were occupied by k-humate foliar application. The main treatments were applied of different nitrogen sources as follows:

$1-100 \%$ of the recommended mineral $\mathrm{N}$ (150kg $\left.\mathrm{Nfed}^{-1}\right)$ ((as ammonium sulphate $\quad 20.5 \% \mathrm{~N}$ source). 
2- $100 \%$ organic $\mathrm{N}\left(150 \mathrm{~kg} \mathrm{Nfed}^{-1}\right)(10.6 \mathrm{t}$ compost fed ${ }^{-1}$ ).

3- $50 \% \mathrm{~N}$ - mineral $\left(75 \mathrm{~kg} \mathrm{Nfed}^{-1}\right)+50 \%$ organic $\mathrm{N}\left(75 \mathrm{~kg} \mathrm{Nfed}^{-1}\right)(5.3 \mathrm{t}$ compost fed $\left.^{-1}\right)$.

Each main plot was randomly subdivided into three sub plots representing the different treatments of $\mathrm{K}$ - humate in a liquid form $\left(10 \% \mathrm{~K}_{2} \mathrm{O}\right)$ as the following:

1- Without addition of K-humate (control).

2- Foliar spraying with 2 L K-humate fed ${ }^{-1}$

3- Foliar spraying with $4 \mathrm{~L} \mathrm{K-humate}$ fed $^{-1}$.

Table (1): Some physical and chemical properties of the studied soil

\begin{tabular}{|c|c|}
\hline Property & Value \\
\hline \multicolumn{2}{|l|}{ Particle size distribution (\%) } \\
\hline Sand & 69.8 \\
\hline Silt & 18.2 \\
\hline Clay & 12 \\
\hline Texture grade & Sandy loam \\
\hline pH (1:2.5 soil water suspension ) & 8.2 \\
\hline ECe (dS/m) (soil paste extract) & 0.87 \\
\hline SP & 29 \\
\hline \multicolumn{2}{|l|}{ Soluble cations (meq/L) } \\
\hline $\mathrm{Ca}^{++}$ & 3.9 \\
\hline $\mathbf{M g}^{++}$ & 2.7 \\
\hline $\mathrm{Na}^{+}$ & 1.85 \\
\hline $\mathrm{K}^{+}$ & 0.55 \\
\hline \multicolumn{2}{|l|}{ Soluble anions (meq/L) } \\
\hline $\mathrm{CO}_{3}{ }^{--}$ & - \\
\hline $\mathrm{HCO}_{3}^{-}$ & 1.3 \\
\hline $\mathrm{Cl}^{-}$ & 4.55 \\
\hline $\mathrm{SO}_{4}{ }^{--}$ & 3.15 \\
\hline Organic matter (\%) & 0.85 \\
\hline \multicolumn{2}{|l|}{ Available (mg kg-1) } \\
\hline $\mathbf{N}$ & 25.4 \\
\hline $\mathbf{P}$ & 10.5 \\
\hline K & 180.51 \\
\hline
\end{tabular}


Table (2): Physical and chemical properties of the compost

\begin{tabular}{|l|c|}
\hline \multicolumn{1}{|c|}{ Properties } & Values \\
\hline EC value (1:10) (dS/m) & 7.90 \\
\hline pH value (1:10) & 6.70 \\
\hline Moisture content (\%) & 28.00 \\
\hline Organic matter (\%) & 44.48 \\
\hline Organic carbon (\%) & 25.80 \\
\hline Total nitrogen (\%) & 1.42 \\
\hline C/N ratio & 18.20 \\
\hline Soluble ammonia-N (mg/Kg) & 615.00 \\
\hline Soluble nitrate-N (mg/Kg) & 362.00 \\
\hline P (\%) & 0.57 \\
\hline K (\%) & 0.82 \\
\hline
\end{tabular}

The organic manure was thoroughly mixed with $0-20 \mathrm{~cm}$ soil surface layer two weeks before sowing. Super phosphate (15\% $\left.\mathrm{P}_{2} \mathrm{O}_{5}\right)$ was added as a single dose at the rate of $30 \mathrm{~kg} \mathrm{P}_{2} \mathrm{O}_{5}$ /fed and mixed in the same times with such surface layer. The nitrogen fertilizer (as ammonium sulphate $20.5 \% \mathrm{~N}$ ) was added according to the treatment in three equal portions, i.e. at 21,35 and 50 days from sowing. Also, potassium fertilizer (as Potassium sulphate, $48 \% \quad \mathrm{~K}_{2} \mathrm{O}$ ) was added at a rate of $24 \mathrm{~kg} \mathrm{~K} \mathrm{~K}_{2} \mathrm{O} / \mathrm{fed}$., which was divided into three equal portions applied with $\mathbf{N}$ fertilizer. Foliar spray of $\mathrm{K}$ humate in a liquid form $\left(10 \% \mathrm{~K}_{2} \mathrm{O}\right)$ was done at $30^{\text {th }}, 45^{\text {th }}$ and $60^{\text {th }}$ days after sowing.

The estimated characteristics at harvesting:

1-Yield and its components:

Plant height (cm), ear characters (i.e., ear length (cm), ear diameter (cm), row numberlear and grain number (row), ear weight, weight of 100 grain (g), grains and biological yield ( $\mathrm{kg} / \mathrm{fed}$.) were measured. For 100 grains weight, grains yield and biological yield were taken after air-dried of the harvested plants based on oven-dried weight on $70^{\circ} \mathrm{C}$ for $48 \mathrm{hrs}$.

\section{II- Chemical analysis}

- Grain samples were taken randomly from the samples of each replicate to determine $\mathrm{N}, \mathrm{P}$ and $\mathrm{K}$ contents. A0.5 g of maize grains of each replicate was digested in a $5 \mathrm{ml}$ of $\mathrm{H}_{2} \mathrm{SO}_{4} \cdot \mathrm{HClO}_{4}$ mixture (3:1 ratio) on sand plate at 250 ${ }^{\circ} \mathrm{C}$ according to the methods described by Chapman and Pratt, (1978). The final clear digestion diluted up to $50 \mathrm{ml}$ using distilled and analyzed for its content of $\mathrm{N}, \mathrm{P}$ and $\mathrm{K}$ as follows:

- Nitrogen (N) content in grains was determined by Keldahl method as described by A.O.A.C. (1990). Protein content in the grains was calculated by multiplying $\mathrm{N} \%$ by 5.75 factor. Phosphorus was determined calorimetrically according to Chapman and Pratt (1978). Potassium was determined by flam photometer according to Page et al., (1982).

- In the sample of maize grains, oil content (\%) was determined by soxhelt 
apparatus using hexane as a solvent as described by A.O.A.C. (1990). Oil and protein yield (kg/fed.) were estimated by multiplying grain yield (kg/fed.) by grain oil and protein percentages respectively.

- Total soluble sugars and total carbohydrates content in the grains were also determined according to Smith et al. (1956). Starch content was obtained by calculating the difference between total carbohydrate and total soluble sugar content.

The obtained results were statistically analyzed according to Gomez and Gomez (1984) to define the statistical significance of L.S.D. at 0.05 .

\section{RESULTS AND DISCUSSION}

The present study aimed to improve the maize productivity and raise the use efficiency of $\mathrm{N}$-fertilization for maize plants through the addition of different nitrogen sources and foliar application of potassium humate. So, data attained herein included the influence of different nitrogen sources application and foliar application of K-humate and their possible combinations on maize grain and biological yields as well as their nutrient contents and quality.

\section{I -Yield and its components}

\section{I.1- Effect of nitrogen sources application}

Data obtained in Tables (3-5) revealed that, the application of nitrogen sources caused a significant increases for plant height, ear length, ear diameter, no. of rows/ear, no. of grains /row, ear weight, 100-grain weight, grain yield and biological yield (kg/fed). The highest yield and its components were found in the plots that received $\mathrm{N}$ from $50 \% \mathrm{~N}$ - mineral $+50 \% \mathrm{~N}-$ org. followed by the plots fertilized with $100 \% \mathrm{~N}$ - mineral and the lowest was found in the plots fertilized by
$100 \% \mathrm{~N}$ - org. The increase in plant height with different nitrogen sources can be attributed to the fact that nitrogen promotes plant growth, increases the number and length of the internodes which results in progressive increase in plant height (Marschner, 1995). More grains ear $^{-1}$ with $\mathrm{N}$ - fertilizer addition may be attributed to enhancing crop growth as a result of compost and mineral $\mathrm{N}$ interaction. Also, may be the consequence of better crop growth due to carry over effect of organic matter and nutrients with continuous compost and mineral $\mathrm{N}$ addition.

Results revealed that cob length in maize differed significantly due to different treatments under study. The increase in the cob length might be due to increase in photosynthetic activities of plant on account of sufficient supply of nitrogen; because $\mathrm{N}$ is essential for cob and kernel growth in maize. Therefore, the development of cob length will be the index of increase in economic yield of maize. The findings of Ali et al. (2012) and Singh et al. (2013) supportive to our results. They found that with the application of $\mathrm{N}$ supply either through mineral or organic source resulted in increasing in cob length. The data on number of grains row $^{-1}$ as influenced by nitrogen sources. Significantly maximum number of grains row $^{-1}$ (49.33) was recorded from plots treated with $50 \% \mathrm{~N}$ mineral $+50 \% \mathrm{~N}$ - org. The increase in number of grains row $^{-1}$ in $\left(T_{7}\right)$ may be attributed to the supply of sufficient amount of nitrogen and other nutrients through different sources required for plant development up to cob formation. Similar results have been reported by Verma and Tomar (2014) and Singh et al. (2013). 
Table (3): Interaction effect of different $\mathrm{N}$ sources and foliar application of $\mathrm{K}$ humate on yield component of maize (average of two seasons)

\begin{tabular}{|c|c|c|c|c|}
\hline \multicolumn{2}{|c|}{ Treatments } & \multirow{2}{*}{$\begin{array}{c}\text { Plant } \\
\text { height } \\
\text { (cm) }\end{array}$} & \multirow{2}{*}{$\begin{array}{l}\text { Ear length } \\
\qquad(\mathrm{cm})\end{array}$} & \multirow{2}{*}{$\begin{array}{l}\text { Ear diameter } \\
\text { (cm) }\end{array}$} \\
\hline N-sources & $\begin{array}{l}\text { Foliar K-humate } \\
\qquad\left(\mathrm{L} \mathrm{fed}^{-1}\right)\end{array}$ & & & \\
\hline \multirow[t]{4}{*}{$100 \% \mathrm{MNF}$} & Control & 259.00 & 20.60 & 4.75 \\
\hline & 2 L K-humate & 275.00 & 23.20 & 5.50 \\
\hline & 4 L K-humate & 284.00 & 25.10 & 5.74 \\
\hline & Mean & 272.67 & 22.97 & 5.33 \\
\hline \multirow[t]{4}{*}{$100 \%$ ONF } & Control & 255.00 & 20.00 & 4.70 \\
\hline & 2 L K-humate & 267.00 & 21.50 & 4.95 \\
\hline & 4 L K-humate & 270.00 & 22.80 & 5.30 \\
\hline & Mean & 264.00 & 21.43 & 4.98 \\
\hline \multirow[t]{4}{*}{$50 \% \mathrm{MN}+50 \% \mathrm{ON}$} & Control & 264.00 & 21.00 & 4.81 \\
\hline & 2 L K-humate & 279.00 & 24.31 & 5.69 \\
\hline & 4 L K-humate & 289.00 & 25.90 & 5.80 \\
\hline & Mean & 277.33 & 23.74 & 5.43 \\
\hline \multirow[t]{3}{*}{ Mean } & Control & 259.33 & 20.53 & 4.75 \\
\hline & 2 L K-humate & 273.67 & 23.00 & 5.38 \\
\hline & 4 L K-humate & 281.00 & 24.6 & 5.61 \\
\hline \multirow[t]{3}{*}{ LSD at $5 \%$} & N-source (A) & 1.95 & 1.41 & 0.19 \\
\hline & Foliar K-humate (B) & 5.58 & 0.61 & 0.48 \\
\hline & AXB & 6.90 & ns & ns \\
\hline
\end{tabular}


Table (4): Interaction effect of different $\mathrm{N}$ sources and foliar application of $\mathrm{K}$ - humate on yield component of maize (average of two seasons)

\begin{tabular}{|c|c|c|c|c|}
\hline \multicolumn{2}{|c|}{ Treatments } & \multirow{2}{*}{$\begin{array}{c}\text { No. of rows I } \\
\text { ear }\end{array}$} & \multirow{2}{*}{$\begin{array}{l}\text { No. of grains } \\
\text { Irow }\end{array}$} & \multirow[b]{2}{*}{ Ear Weight } \\
\hline $\mathrm{N}$-sources & $\begin{array}{l}\text { Foliar K-humate } \\
\qquad\left(\text { L fed }^{-1}\right)\end{array}$ & & & \\
\hline \multirow{4}{*}{$100 \%$ MNF } & Control & 14.33 & 46.33 & 255.00 \\
\hline & 2 L K-humate & 15.00 & 55.67 & 290.21 \\
\hline & 4 L K-humate & 16.00 & 58.00 & 300.00 \\
\hline & Mean & 15.11 & 53.33 & 281.74 \\
\hline \multirow{4}{*}{$100 \%$ ONF } & Control & 13.00 & 43.00 & 249.14 \\
\hline & 2 L K-humate & 14.00 & 50.00 & 275.13 \\
\hline & 4 L K-humate & 15.00 & 52.00 & 282.00 \\
\hline & Mean & 14.00 & 48.33 & 268.76 \\
\hline \multirow{4}{*}{$50 \% \mathrm{MN}+50 \% \mathrm{ON}$} & Control & 14.67 & 49.33 & 265.22 \\
\hline & 2 L K-humate & 16.00 & 57.33 & 295.55 \\
\hline & 4 L K-humate & 17.00 & 60.00 & 322.62 \\
\hline & Mean & 15.89 & 55.56 & 294.46 \\
\hline \multirow{3}{*}{ Mean } & Control & 14.00 & 46.22 & 256.45 \\
\hline & 2 L K-humate & 15.00 & 54.33 & 286.96 \\
\hline & 4 L K-humate & 16.00 & 56.67 & 301.54 \\
\hline \multirow{3}{*}{ LSD at $5 \%$} & N-source $(A)$ & 1.25 & 2.57 & 3.52 \\
\hline & Foliar K-humate (B) & 1.46 & 2.32 & 1.82 \\
\hline & $A X B$ & ns & 3.00 & 9.74 \\
\hline
\end{tabular}


Table (5): Interaction effect of different $\mathrm{N}$ sources and foliar application of K-humate on yield and its component of maize (average of two seasons)

\begin{tabular}{|c|c|c|c|c|}
\hline \multicolumn{2}{|c|}{ Treatments } & \multirow{2}{*}{$\begin{array}{l}\text { Weight of } \\
100 \text { grain }\end{array}$} & \multirow{2}{*}{$\begin{array}{l}\text { Grain Yield } \\
\text { (kg/fed) }\end{array}$} & \multirow{2}{*}{$\begin{array}{l}\text { Biologica } \\
\text { (kg/fed) }\end{array}$} \\
\hline $\mathrm{N}$-sources & $\begin{array}{l}\text { Foliar K-humate } \\
\qquad\left(\mathrm{L} \mathrm{fed}^{-1}\right)\end{array}$ & & & \\
\hline \multirow{4}{*}{$100 \% \mathrm{MNF}$} & Control & 35.27 & 3570.67 & 7625.00 \\
\hline & 2 L K-humate & 39.55 & 3925.00 & 8277.33 \\
\hline & 4 L K-humate & 41.65 & 4100.00 & 8625.00 \\
\hline & Mean & 38.82 & 3865.22 & 8175.78 \\
\hline \multirow{4}{*}{$100 \%$ ONF } & Control & 33.20 & 3296.00 & 7510.33 \\
\hline & 2 L K-humate & 37.78 & 3750.33 & 7991.67 \\
\hline & 4 L K-humate & 38.44 & 3862.00 & 8193.00 \\
\hline & Mean & 36.47 & 3636.11 & 7898.33 \\
\hline \multirow{4}{*}{$50 \% \mathrm{MN}+50 \% \mathrm{ON}$} & Control & 36.90 & 3693.33 & 7732.67 \\
\hline & 2 L K-humate & 40.77 & 4000.33 & 8395.67 \\
\hline & 4 L K-humate & 43.00 & 4180.67 & 8843.00 \\
\hline & Mean & 40.22 & 3958.11 & 8323.78 \\
\hline \multirow{3}{*}{ Mean } & Control & 35.12 & 3520.00 & 7622.67 \\
\hline & 2 L K-humate & 39.37 & 3891.89 & 8221.56 \\
\hline & 4 L K-humate & 41.03 & 4047.56 & 8553.67 \\
\hline \multirow{3}{*}{ LSD at $5 \%$} & N-source (A) & 2.24 & 58.75 & 64.76 \\
\hline & $\begin{array}{l}\text { Foliar K-humate } \\
\text { (B) }\end{array}$ & 3.27 & 48.44 & 161.65 \\
\hline & AXB & 3.74 & 78.05 & 54.77 \\
\hline
\end{tabular}

The data on cob weight as influenced by various treatments under study has been presented in Table (4). Perusal of the data showed that weight of cob was significantly influenced by nitrogen sources. Significantly maximum cob weight $(265.22 \mathrm{~g})$ was recorded from plots treated with $50 \% \mathrm{~N}$ - mineral $+50 \%$
$\mathrm{N}$ - org. The higher cob weight was attributed to higher grain number row ${ }^{-1}$ and grains per cob. Data pertaining to 100-grain weight of maize as influenced by nitrogen sources have been furnished in Table (5). Significantly boldest grain with test weight of 36.90 and $35.27 \mathrm{~g}$ were obtained at $50 \% \mathrm{~N}$ - mineral $+50 \% \mathrm{~N}$ - org 
and $100 \% \mathrm{~N}$ - mineral respectively. Increased 100-grain weight of maize with through mineral or organic $\mathrm{N}$ - source may be due to the formation of more leaf area which might have intercepted more light and produced more carbohydrates in the source which was probably translocated into the sink (the grain) and resulted in increased kernel weight.

Maize yield is a function of different yield components such as the length and girth of cob, number of rows per cob, number of grains per row, 100-grain weight and shelling percentage. The data pertaining to grain yield of maize as influenced by various treatments under study have been presented in Table (5) and Fig. (1). It is evident from the results that grain yield of maize influenced significantly due to nitrogen sources. Increase in grain yield was therefore, due to significant increase in cob length, grain number per cob and 100-grain weight. The highest grain yield was found in the plots that received $\mathrm{N}$ from $50 \% \mathrm{~N}$ mineral $+50 \% \mathrm{~N}$ - org. (3693.33 Kg/fed) followed by the plots fertilized with $100 \%$
$\mathrm{N}$ - mineral (3570.67 Kg/fed) and the lowest one was found in the plots fertilized with $100 \% \mathrm{~N}$ - org. (3296.00 $\mathrm{Kg} / \mathrm{fed})$ respectively. Research results from Hammad et al. (2013) also suggest that $\mathbf{N}$ application had much greater effect on maize grain yield which could be due to the fact that application of $\mathrm{N}$ fertilizer in plants increases uptake of other nutrients. This can be explained by the fact that the supply of $\mathbf{N}$ enhanced the development of small roots and root hairs which, in turn, facilitate the absorbing ability per unit of dry weight. The better grain yield with combined application could be attributed to better growth, yield attributing components, grain development and nutrient use efficiencies. Our results are similar to the findings of Nagassa et al. (2005) and Shah et al. (2009), they revealed that grain yield was significantly affected by $\mathbf{N}$ fertilizer in combination with FYM. In addition, Ayoola and Makinde (2009) reported higher nutrient use efficiencies by combining organic and inorganic fertilizers.

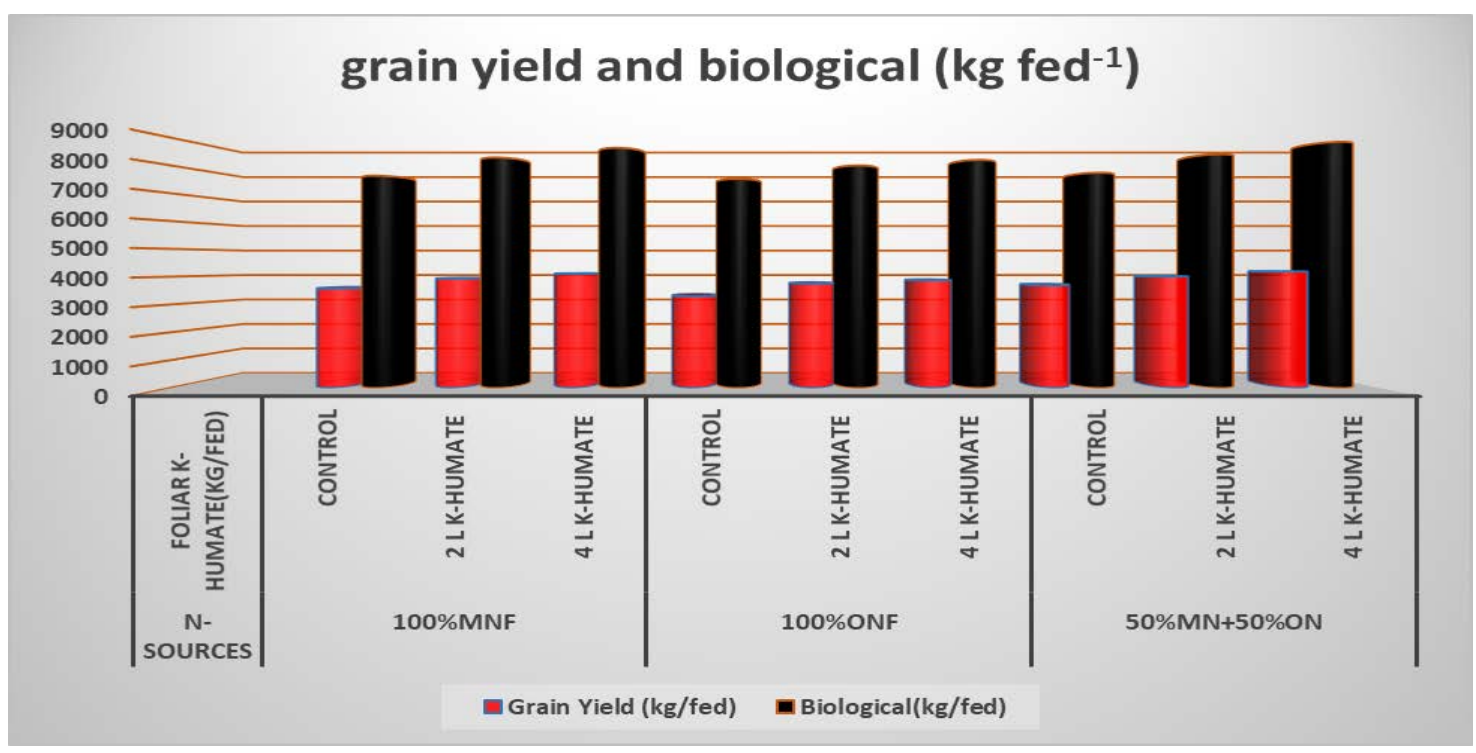

Fig. (1): Interaction effect of different $\mathrm{N}$ sources and foliar application of K-humate on yield of maize . 
Biological yield is one of the measures of plant growth and it reflects the relative growth rate as regard to net assimilation rate (Khan et al. 2008). Data pertaining to biological yield as affected by application of nitrogen sources is presented in Tables (3-5). Biological yield differed significantly among various nitrogen sources. The lowest value for biological yield was statistically with $100 \% \mathrm{~N}$ - org. Data revealed that biological yield of maize varied from maximum $(7732.67 \mathrm{Kg} / \mathrm{fed})$ in $50 \% \mathrm{~N}$ mineral $+50 \% \mathrm{~N}$ - org. $\left(\mathrm{T}_{7}\right)$ to lowest value $(7510.33 \mathrm{Kg} / \mathrm{fed}$ ) observed in $100 \% \mathrm{~N}$ - org. These increases may be attributed to the beneficial effects of nitrogen on stimulating the meristmatic activity for producing more tissues and organs, since nitrogen plays major roles in the synthesis of structural proteins and other several macro molecules, in addition to its vital contribution in several biochemical processes in the plant related to growth (Marschner, 1995). Moreover, the positive effect on growth traits by using compost manure might be soil application of compost increases the soil organic matter percentage that has been regarded a key factor determining soil fertility and productivity (Sarwar et al. 2007). The addition of compost improves the physical properties of the soil and decreases its $\mathrm{pH}$ value, as a result, the availability of soil nutrients for plants increased and various yield components were positively affected and ultimately these components contributed towards increasing of grain and straw yields (Sarwar, 2005).

\section{I.2-Effect of foliar application of potassium humate}

Concerning the effect of spraying maize plants with potassium humate at rates (control, 2 and $4 \mathrm{~L}$ /fed) on plant height, ear length, ear diameter, no. of rows/ear, no. of grains/row, 100 -grain weight, grain yield and biological yield $\mathrm{kg} / \mathrm{fed}$. It is obvious from Tables (3-5) that yield and its components were gradually increased with increasing potassium humate rate from 0 to $4 \mathrm{~L}$ /fed. These results may be due to potassium humate which contains humic acid, fulvic acid and $\mathrm{K}_{2} \mathrm{O}$ at rate $86 \%, 17 \%$ and $10 \%$, respectively, which reflected a positive effect on vegetative growth. Moreover, Potassium presented within plants as the cation $\mathrm{K}^{+}$, plays an important role in regulation of the osmotic potential of plant cells and activates many enzymes involved in respiration and photosynthesis (Marschner, 1995). Furthermore, the effective role of foliar spraying on both maize grain and straw yields and their nutrient contents could be ascribed to that humic molecules can get into the cellular nutrient stream and make the cellular membrane more permeable allowing the improvement of nutrient flow and cell division (Allam, 2006). These results could be explained according to the finding of Cheng et al. (1998) who found that spraying humic acid enhanced the water retention, increased the ability rate of wheat leaves for photosynthetic process, increased the grain filling intensity, enhanced the drought resistance of wheat and increased its thousand grain weight.

\section{I.3- Combined effect of nitrogen sources and potassium humate rates \\ Data resented in Tables (3-5)} illustrated the effect of the combined application of nitrogen sources and foliar application of potassium humate rates on yield and its components. It is clearly that all interactions between nitrogen sources and potassium humate rates had a significant effect on plant height, no. of grains /row, 100 -grain weight, grain yield and biological yield $\mathrm{kg} / \mathrm{fed}$ except ear length, ear diameter and no. of rows/ear. The most increases in the yield and its components were observed with plants fertilized with $50 \% \mathrm{~N}$ - mineral $+50 \% \mathrm{~N}$ - 
org. and foliar application of potassium humate at $4 \mathrm{~L} / \mathrm{fed}\left(\mathrm{T}_{9}\right)$ as compared to the other interaction treatments. High significant grain yield of $4180.67(\mathrm{~kg} / \mathrm{fed})$ was produced by the combination treatment of $50 \% \mathrm{~N}$ - mineral $+50 \% \mathrm{~N}$ - org. and foliar application of potassium humate at $4 \mathrm{~L} / \mathrm{fed}\left(\mathrm{T}_{9}\right)$ which was found to be superior to all other treatment combinations.

\section{II-Nutrient uptake by maize grains} II.1-Effect of nitrogen sources application

Nitrogen uptake by grains of maize plants was significantly different due to nitrogen sources (Table, 6). Significantly higher amount of N-uptake was withdrawn by the grain (viz., $66.86 \mathrm{~kg} / \mathrm{fed}$ ) of maize treated with $50 \%$ mineral $\mathrm{N}+$ $50 \%$ as organic $\mathrm{N}$. The increase in uptake of $\mathrm{N}$ may be due to better availability and absorption of nitrogen in balanced quantity because of good proliferation of root system. The results corroborate with the findings of Sujatha et al. (2008) and Singh et al. (2013). Conjoint application of $50 \%$ mineral $N+\mathbf{5 0 \%}$ as organic also recorded higher $P$ and $K$ uptake compared to nitrogen sources. The beneficial effects of using organic fertilizers along with mineral $-\mathrm{N}$ fertilizer on increasing nutrient uptake of maize grains could be due to their effect on providing plants with their requirements from different nutrients at a longer time as well as their effect on increasing the availability of nutrients in the soil for uptake by plants and enhancing the nutritional status of the plants.

Table (6): Combined effect of different $\mathrm{N}$ sources and foliar application of K-humate on nutrient uptake by maize grain (average of two seasons)

\begin{tabular}{|c|c|c|c|c|}
\hline \multicolumn{2}{|c|}{ Treatments } & \multirow[b]{2}{*}{$\begin{array}{l}\text { N- uptake } \\
\left(\mathrm{Kg} \mathrm{fed}^{-1}\right)\end{array}$} & \multirow[b]{2}{*}{$\begin{array}{l}\text { P- uptake } \\
\left(\text { Kg fed }^{-1}\right)\end{array}$} & \multirow[b]{2}{*}{$\begin{array}{r}\text { K- uptake } \\
\left(\mathrm{kg} \mathrm{fed}^{-1}\right)\end{array}$} \\
\hline $\mathrm{N}$-sources & $\begin{array}{c}\text { Foliar K- } \\
\text { humate } \\
\left(\mathrm{L} \mathrm{fed}^{-1}\right)\end{array}$ & & & \\
\hline \multirow{4}{*}{$100 \% \mathrm{MNF}$} & Control & 62.48 & 12.79 & 25.68 \\
\hline & 2 L K-humate & 77.32 & 15.87 & 33.44 \\
\hline & 4 L K-humate & 85.28 & 17.71 & 38.87 \\
\hline & Mean & 75.03 & 15.46 & 32.66 \\
\hline \multirow{4}{*}{$100 \%$ ONF } & Control & 56.02 & 10.44 & 24.67 \\
\hline & 2 L K-humate & 68.62 & 14.25 & 30.71 \\
\hline & 4 L K-humate & 72.62 & 15.11 & 32.32 \\
\hline & Mean & 65.76 & 13.27 & 29.24 \\
\hline \multirow{4}{*}{$\begin{array}{c}50 \% M N+50 \% O \\
N\end{array}$} & Control & 66.86 & 13.70 & 28.73 \\
\hline & 2 L K-humate & 80.00 & 16.79 & 35.64 \\
\hline & 4 L K-humate & 91.96 & 18.30 & 41.47 \\
\hline & Mean & 79.61 & 16.26 & 35.28 \\
\hline \multirow{3}{*}{ Mean } & Control & 61.79 & 12.31 & 26.36 \\
\hline & 2 L K-humate & 75.31 & 15.64 & 33.26 \\
\hline & 4 L K-humate & 83.29 & 17.04 & 37.55 \\
\hline \multirow{3}{*}{ LSD at $5 \%$} & $\mathrm{~N}$-source $(\mathrm{A})$ & 2.38 & 0.95 & 2.06 \\
\hline & $\begin{array}{c}\text { Foliar K- } \\
\text { humate (B) }\end{array}$ & 2.76 & 0.79 & 1.54 \\
\hline & AXB & 3.70 & ns & 2.76 \\
\hline
\end{tabular}


II.2-Effect of foliar application of potassium humate

The obtained results are also shown in Table (6) and Fig. (2) show a significant increases in nitrogen, phosphorus and potassium uptake by grains of maize plants were recorded for plants received different treatments particularly, for plants received $50 \%$ mineral $\mathrm{N}+50 \%$ as organic $\mathrm{N}$ plus foliar application. In general nutrients uptake increased by increasing rates of $\mathrm{K}$ humate foliar application. Combination with $50 \%$ mineral $\mathrm{N}+\mathbf{5 0 \%}$ as organic $\mathrm{N}$ and foliar application of potassium humate at 4L/fed ( $\left.\mathrm{T}_{9}\right)$ followed by $\mathrm{T3}$, $(100 \%$ mineral $\mathrm{N}+$ potassium humate at 4L/fed) and $\mathrm{T}_{8}$ (50\% mineral $\mathrm{N}+\mathbf{5 0 \%}$ as organic $\mathrm{N}+$ potassium humate at $2 \mathrm{~L} / \mathrm{fed}$ ) increased nutrient (NPK) uptake compared to $(100 \%$ ONF). The $N$ uptake varied from 56.02 to $91.96 \mathrm{~kg} / \mathrm{fed}$ in favor of T9 which was significantly different from other treatments (Table 6). The maximum $P$ uptake was obtained from T9 (50\% mineral $N+50 \%$ as organic $N+$ potassium humate at $4 \mathrm{~L} / \mathrm{fed}$ ) followed by T3 (100\% mineral $\mathrm{N}+$ potassium humate at $4 \mathrm{~L} / \mathrm{fed})$ and T8 (50\% mineral $\mathrm{N}+50 \%$ as organic $\mathrm{N}+$ potassium humate at 2L/fed). The highest $\mathrm{K}$ uptake (41.47 $\mathrm{kg} / \mathrm{fed}$.) was observed in T9 followed by T3 $(38.87 \mathrm{~kg} / \mathrm{fed})$. The beneficial effects of using organic fertilizers along with mineral $-\mathrm{N}$ fertilizer on increasing nutrient uptake of maize grains could be due to their effect on providing plants with their requirements from different nutrients at a longer time as well as their effect on increasing the availability of nutrients in the soil for uptake by plants and enhancing the nutritional status of the plants.

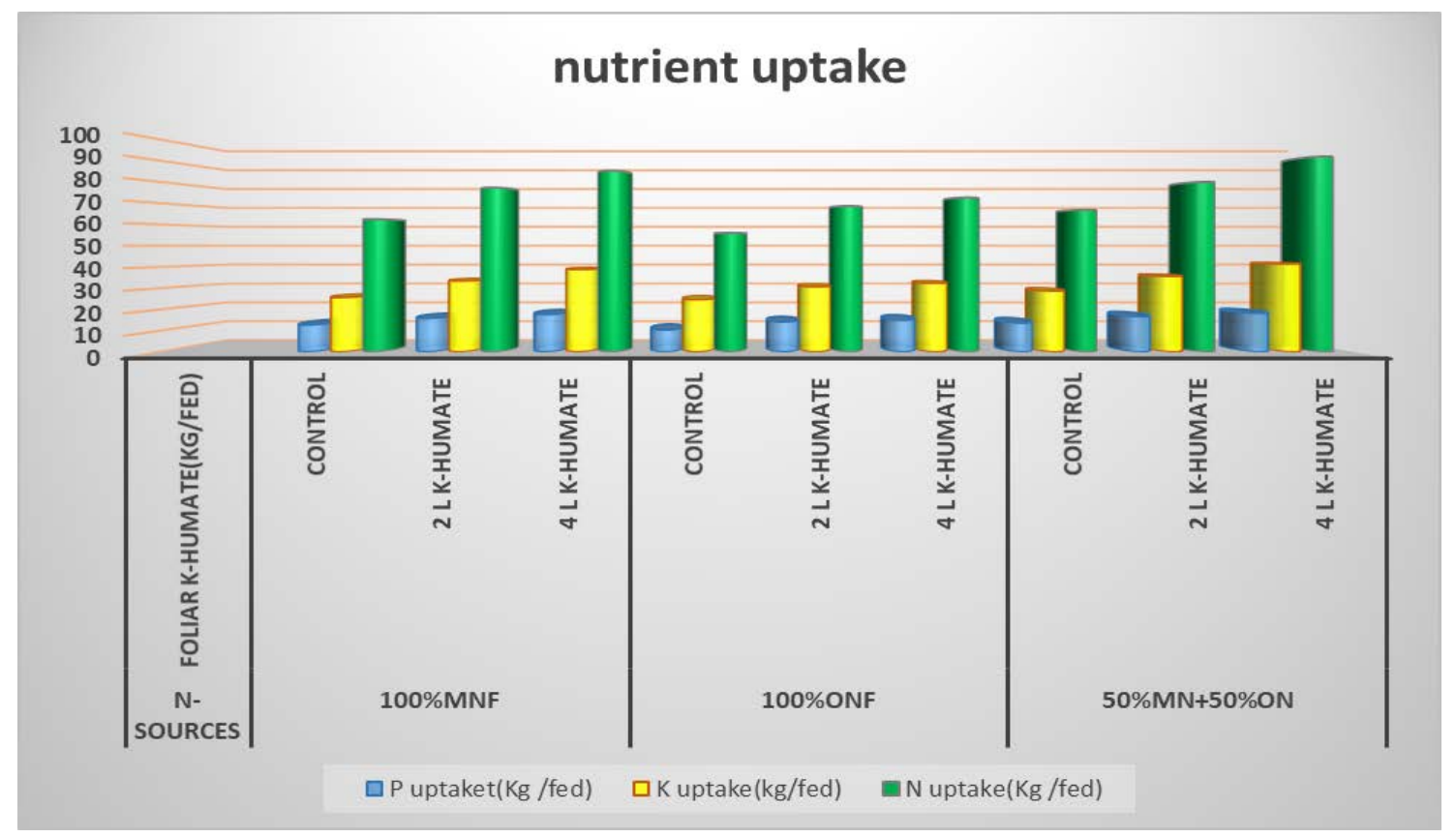

Fig. (2): Combined effect of different $\mathrm{N}$ sources and foliar application of K-humate on nutrients uptake by maize grain 
The foliar application of potassium humate at a rate of $4 \mathrm{LI}$ fed combined with $50 \%$ mineral $\mathrm{N}+\mathbf{5 0 \%}$ as organic $\mathrm{N}$ was more effective on $\mathrm{N}, \mathrm{P}$ and $\mathrm{K}$ uptake by grain of maize plants than other treatments. K-humate foliar application derivatives is reported to be very effective because the humic molecules can get into the cellular nutrient stream and make the cellular membrane more permeable allowing the improvement of nutrient flow and cell division (Jackson, 1993). The need to exploit the capacity of plant leaves to absorb inorganic nutrients has increased greatly for a number of reasons (i) adverse soil conditions which favor fixation of nutrients and thus render many essential ones unavailable for root absorption; (ii) root absorption is slow for some elements and also results in poor translocation; (iii) relatively large amounts of fertilizers are required for root supply and heavy application loads to soil-water pollution. Foliar supply of nutrients can result in increasing the photosynthetic efficiency and it is possible to modify the physiology of leaf. The application of K-humate was more effective on the uptake of $N, P$ and $K$ by maize plants as compared to unenriched $\mathrm{K}$-humate. This could be related to, direct effects of humic substances on plant cell membranes, and consequently permeability, which ease mineral elements move back and forth through the cell membranes, resulting in an increased transport of various mineral nutrients to sites of metabolic need. These results are in good agreement with those obtained by Salib (2002); Lamont (2003) and Rafla (2012) who found that, the application of humic acid had a definite impact on the yield and nutrients uptake as well as protein and nucleic acids contents.

\section{II.3-Combined effect of nitrogen sources and potassium humate rates}

Data presented in Table (6) indicated that the interaction between nitrogen sources and potassium humate rates had significant effect on N, P and K uptake, and the most effective interaction treatment was fertilized with $50 \% \mathrm{~N}$ mineral $+50 \% \quad \mathrm{~N}-$ Org. and foliar application of potassium humate at 4L/fed $\left(T_{9}\right)$, which recorded the highest values of $\mathrm{N}, \mathrm{P}$ and $\mathrm{K}$ uptake as compared to other treatments.

\section{III-Chemical composition of maize grains \\ III.1-Effect of the applied treatments on grain quality of maize}

The grain quality of maize in terms of their protein, oil and carbohydrate content were improved with different nitrogen sources in Tables (7 and 8) and Fig (3). The data exhibited significant effect of nitrogen sources treatments on grain protein contents as well as protein yield of maize. Significantly highest grain protein viz., $10.41 \%$ was determined in grains of the plot subjected to $50 \% \mathrm{~N}$ mineral $+50 \% \mathrm{~N}$ - org. While, the treatment of $100 \%$ ONF treatment gave the lowest crude protein as compared with the other nitrogen sources. Increase in grain protein content might be due to increase in $\mathrm{N}$ content of leaves which are rapidly converted to protein and during grain development leaf $\mathrm{N}$ is transferred to grain for protein production. Increasing of protein content definitely, may be due to the fact that nitrogen often plays a great role in the synthesis of protein. Similar results regarding the increased percentage of crude protein due to applied nitrogen were obtained by several researchers, (Parasad, 1979; Gangwar and Kalra, 1988 and Singh et al. 1992). In regards to protein yield, it follows the same trend as has been observed in grain yield of maize in the 
present experiment. The favorable effect of $\mathbf{N}$ fertilizer on protein yield $\mathrm{fed}^{-1}$ might be explained by assuming an influence of $\mathbf{N}$ availability on critical stage of grain initiation and development of plant metabolism in away leading to the increase in the synthesis of amino-acid and their incorporation into grain protein.

Oil content (\%) of maize grains was significantly affected by different nitrogen sources in Table (6). Significantly maximum oil content was determined in the treatment of $50 \%$ mineral $\mathrm{N}+50 \%$ as organic $\mathrm{N}(5.85 \%)$ while, the $100 \%$ ONF treatment gave the lowest oil content as compared with the other nitrogen sources Biochemical analysis revealed that, results given in
Table (8) cleared that carbohydrate contents, starch and TSS parameters were statistically affected by different nitrogen sources. The significant increase in total carbohydrate, starch and TSS concentration by nitrogen sources application might be due to that the nitrogen is essential in the structure of porphyrines, which are found in cytochrome enzymes. This increase in the cytochrome enzymes results in an increase in the rate of photosynthesis, and consequently in a promotion of carbohydrate synthesis and its accumulation in grains, these results agreed with those obtained by Attia and Saad (2001)

Table (7): Combined effect of different $\mathrm{N}$ sources and foliar application of K-humate on quality of maize grain (average of two seasons)

\begin{tabular}{|c|c|c|c|c|c|}
\hline \multicolumn{2}{|c|}{ Treatments } & \multirow[b]{2}{*}{ Protein \% } & \multirow[b]{2}{*}{$\begin{array}{l}\text { Protein Yield } \\
\qquad\left(\mathrm{kg} \mathrm{fed}^{-1}\right)\end{array}$} & \multirow[b]{2}{*}{ Oil\% } & \multirow[b]{2}{*}{$\begin{array}{l}\text { Oil yield } \\
\left(\mathrm{Kg} \mathrm{fed}^{-1)}\right.\end{array}$} \\
\hline $\mathrm{N}$-sources & $\begin{array}{l}\begin{array}{l}\text { Foliar K- } \\
\text { humate } \\
\left(\mathrm{L} \mathrm{fed}^{-1}\right)\end{array} \\
\end{array}$ & & & & \\
\hline \multirow{4}{*}{$100 \%$ MNF } & Control & 10.06 & 359.28 & 5.47 & 195.31 \\
\hline & 2 L K-humate & 11.33 & 444.67 & 7.20 & 282.58 \\
\hline & 4 L K-humate & 11.96 & 490.53 & 7.90 & 323.90 \\
\hline & Mean & 11.12 & 431.50 & 6.86 & 267.26 \\
\hline \multirow{4}{*}{$100 \%$ ONF } & Control & 9.78 & 322.19 & 5.00 & 164.80 \\
\hline & 2 L K-humate & 10.52 & 394.50 & 6.55 & 245.69 \\
\hline & 4 L K-humate & 10.81 & 417.70 & 6.80 & 262.66 \\
\hline & Mean & 10.37 & 378.13 & 6.12 & 224.38 \\
\hline \multirow{4}{*}{$\begin{array}{c}50 \% \mathrm{MN}+50 \% \\
\mathrm{ON}\end{array}$} & Control & 10.41 & 384.49 & 5.85 & 216.05 \\
\hline & 2 L K-humate & 11.50 & 460.14 & 7.50 & 300.01 \\
\hline & $4 \mathrm{~L}$ K-humate & 12.65 & 528.78 & 8.00 & 334.43 \\
\hline & Mean & 11.52 & 457.80 & 7.12 & 283.50 \\
\hline \multirow{3}{*}{ Mean } & Control & 10.08 & 355.32 & 5.44 & 192.05 \\
\hline & 2 L K-humate & 11.12 & 433.10 & 7.08 & 276.09 \\
\hline & $4 \mathrm{~L}$ K-humate & 11.81 & 479.01 & 7.57 & 307.00 \\
\hline \multirow{3}{*}{ LSD at $5 \%$} & N-source (A) & 0.23 & 13.65 & 0.32 & 9.13 \\
\hline & $\begin{array}{c}\text { Foliar K- } \\
\text { humate (B) }\end{array}$ & 0.54 & 15.94 & 0.23 & 12.18 \\
\hline & AXB & 0.51 & 21.23 & ns & ns \\
\hline
\end{tabular}


Table (8): Interaction effect of different $\mathbf{N}$ sources and foliar application of K-humate on quality of maize grain (average of two seasons).

\begin{tabular}{|c|c|c|c|c|}
\hline \multicolumn{2}{|c|}{ Treatments } & \multirow[b]{2}{*}{ T.C \% } & \multirow[b]{2}{*}{ Starch \% } & \multirow[b]{2}{*}{ TSS\% } \\
\hline $\mathrm{N}$-sources & $\begin{array}{l}\text { Foliar K- } \\
\text { humate } \\
\left(\mathrm{L} \mathrm{fed}^{-1}\right)\end{array}$ & & & \\
\hline \multirow{4}{*}{$100 \%$ MNF } & Control & 65.27 & 63.38 & 1.89 \\
\hline & 2 L K-humate & 72.00 & 69.60 & 2.40 \\
\hline & 4 L K-humate & 74.10 & 71.36 & 2.74 \\
\hline & Mean & 70.46 & 68.11 & 2.34 \\
\hline \multirow{4}{*}{$100 \%$ ONF } & Control & 63.12 & 61.32 & 1.80 \\
\hline & 2 L K-humate & 69.00 & 66.78 & 2.22 \\
\hline & 4 L K-humate & 70.14 & 67.84 & 2.30 \\
\hline & Mean & 67.42 & 65.31 & 2.11 \\
\hline \multirow{4}{*}{$50 \% \mathrm{MN}+50 \% \mathrm{ON}$} & Control & 67.04 & 64.89 & 2.15 \\
\hline & 2 L K-humate & 73.24 & 70.68 & 2.56 \\
\hline & 4 L K-humate & 74.58 & 71.78 & 2.80 \\
\hline & Mean & 71.62 & 69.12 & 2.50 \\
\hline \multirow{3}{*}{ Mean } & Control & 65.14 & 63.20 & 1.95 \\
\hline & 2 L K-humate & 71.41 & 69.02 & 2.39 \\
\hline & 4 L K-humate & 72.94 & 70.33 & 2.61 \\
\hline \multirow{3}{*}{ LSD at $5 \%$} & N-source (A) & 0.65 & 0.71 & 0.09 \\
\hline & $\begin{array}{c}\text { Foliar K- } \\
\text { humate (B) }\end{array}$ & 0.76 & 0.63 & 0.11 \\
\hline & AXB & 1.90 & 1.92 & 0.09 \\
\hline
\end{tabular}

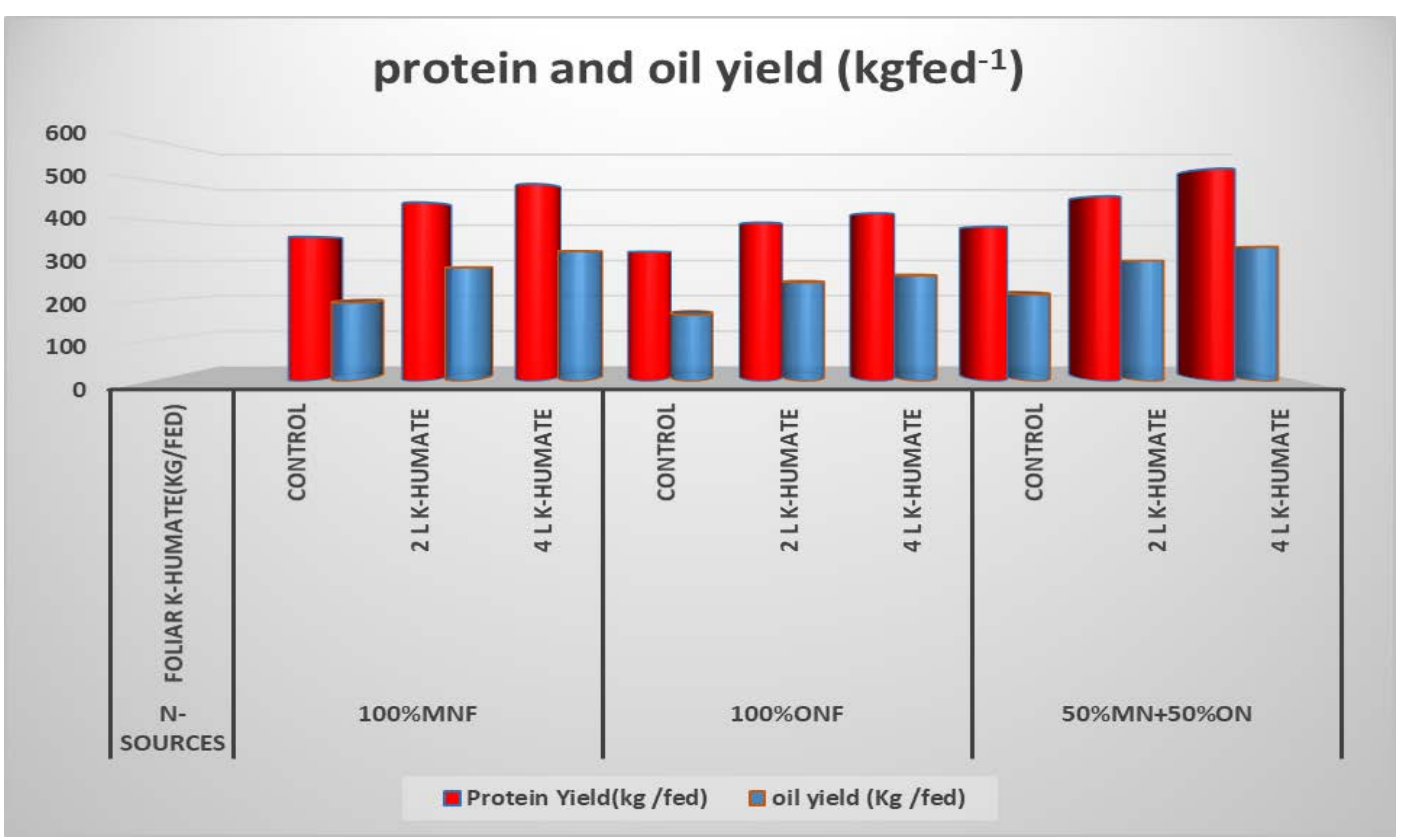

Fig. (3): Combined effect of different $\mathrm{N}$ sources and foliar application of K-humate on quality of maize grain 
III.2-Effect of foliar application of potassium humate on yield quality

Quality of maize yield due to application of potassium humate as foliar application are given in Tables (7 and 8). The obtained results indicate that, the protein, oil, starch, TSS and carbohydrate contents in grain of maize were significantly increased as a result of all the tested treatments. The foliar application with potassium humate was more effective on protein, oil, starch, T.S.S and carbohydrate contents in grain of maize. The highest protein content was obtained with $\mathrm{T}_{9}(50 \%$ mineral $\mathrm{N}+$ $50 \%$ as organic $\mathrm{N}$ and foliar application of potassium humate at $4 \mathrm{~L} / \mathrm{fed}$ ) followed by $\mathrm{T}_{3}(100 \%$ mineral $\mathrm{N}+$ potassium humate at 4 L/fed) followed by $\mathrm{T}_{8}(50 \%$ mineral $\mathrm{N}$ $+50 \%$ as organic $N+$ potassium humate at 2L/fed). From Table (7), it is clear that protein yield significantly increased with inorganic fertilizer more than organic fertilizer. Protein yield fed $^{-1}$ was also significantly affected by the applied treatments. The applied different treatment combinations caused increases in grain oil content and oil yield (Table 7). $\mathrm{T}_{9} \quad(50 \%$ mineral $+50 \%$ organic $\mathrm{N}+$ potassium humate at $4 \mathrm{~L} / \mathrm{fed}$ ) recorded the highest oil content $(8.00 \%)$ and oil yield $\left(334.43 \mathrm{~kg} \mathrm{fed}^{-1}\right)$. The highest values of carbohydrates were recorded $\mathbf{7 4 . 5 8 \%}$ for $\mathrm{T}_{9} \quad(50 \%$ mineral $+50 \%$ organic $\mathrm{N}+$ potassium humate at 4L/fed). These results indicated that carbohydrate content has increased due to the combined effects of the interactions between nitrogen sources and potassium humate rates. These findings are previously reported by Mahfouze and Sharaf El-din (2007) who recorded an increase of the total carbohydrate content by the application of potassium humate at $4 \mathrm{~L} / \mathrm{fed}$ combined with $\mathbf{5 0 \%}$ mineral $+50 \%$ organic $N$. Our findings were in accordance with the previous reports which highlighted the positive effect of compost in improving soil physical properties which enhances root development, water and nutrients uptake and consequently improve maize yield and grain quality (Brady and Weil, 2005 and Habashy and Hemeid, 2011). This may be explained due to the role of humic substances in increasing the concentration of messenger ribonucleic acids in plant cell. Messenger ribonucleic acids is essential for many biochemical processes within cells. Activation of several biochemical processes results in an increase in enzyme synthesis and an increase in the protein and carbohydrate contents, as found by Neri et al. (2003). Plant nutrition within foliar fertilizers are rapidly absorbed by the plant leaves and have positive effects on physiological processes into plant.

III.3-Combined effect of nitrogen sources and potassium humate rates

Combination of nitrogen sources with potassium humate as foliar application were more effective on protein, oil, starch, TSS and carbohydrate contents in grain of maize as compared to nitrogen sources alone.

\section{Conclusion}

The findings of this study have clearly showed that combined application of $50 \%$ mineral $+50 \%$ organic $N$ along with foliar application of potassium humate at 4L/fed had resulted in obtaining highest plant growth, yield and quality of maize.

\section{REFERENCES}

Abdel Mawgoud, A., M.R.N. El- Greadly, Y.I. Helmy and S.M. Singer (2007). Responses of tomato plants to different rates of humic based fertilizer and NPK fertilization. J. of App. Sci. Res. 3: 169-174.

Ali, K., F. Munsif, I. Uddin, A. Abid Khan and N. Khan (2012). Maize penology as affected by tillage practices and nitrogen sources. Agric. Scie. Res. J. 2(8): 453-458. 
Allam, S.M. (2006). Foliar spray for plant growth. Down Internet edition Zihaj.3:1427.

A.O.A.C. (1990). Association of Official Analytical Chemists. Official Methods of Analysis. $15^{\text {th }}$ ed., Washington, D.C., USA.

Attia, F.A. and O.A.O. Saad (2001). Bio fertilizers as partial alternative of chemical fertilizer for Catharanthus roseus, G. Don. J. Agric. Sci. Mansoura Univ., 26 (11): 7193-7208.

Ayoola, O.T. and E.A. Makinde (2009). Maize growth, yield and soil nutrient changes with $\mathrm{N}$-enriched organic fertilizers. Afr. J. Food Agric. Nutr. Dev., 9: 580-592.

Brady, N.C. and R. Weil (2005). The Nature and Properties of Soil, $13^{\text {rd }}$. edition. Macmillan Publishing Co, New York.

Bryan, H. and J. Stark (2003). Humic acid effects on potato response to phosphorus. IJaho Potato Conference, USA, January 22-23, 5 pp.

Chapman, H.D. and R.T. Pratt (1978). "Methods of Analysis for Soils, Plants and Water" Univ. of California, Div. Agric. Sci. Priced Publication 4030, pp: 12-19.

Chen, Y. and T. Aviad (1990). Effects of humic substances on plant growth. In: Humic Substances in Soil and Crop Sciences Amer. J. Soil Sci. 34:161-186.

Cheng, F.J., D.Q. Yang and Q.S. Wu (1998). Physiological effects of humic acid on drought resistance of wheat. Chinese J. of Applied Ecology. 4-6: 363-367

Farhad, W., M.F. Saleem, M.A. Cheema and H.M. Hammad (2009). Effect of poultry manure levels on the productivity of spring maize (Zea mays L.). J. Anim. Plant Sci. 19(3): 122-125.

Gangwar, B. and G.S. Kalra (1988). Influence of maize legume associations and nitrogen levels on maturity, grain quality and protein productivity. Field Crop Abstr. 41 (11): 917

Gomez, K.A. and C.M. Gomez (1984). Statistical procedure for agricultural research. J ohn Wiley and Sons Inc, New Tork.

Habashy, N.R. and N.M. Hemeid (2011). Effects of elemental sulphur and partial substitution of $\mathrm{N}$-mineral fertilizer by organic amendments on some properties of slight saline soils. J. App. Sci. Res. 7(12): 2102- 2111.

Haghighi, S., T. Saki Nejad and Sh. LacK (2011). Evaluation of changes the qualitative \& quantitative yield of horse bean (Vicia FabaL) plants in the levels of humic acid fertilizer. Life Science Journal 8(3).

Hammad, H. M., A. Ahmad, W. Farhad, A. Farhat, K. Qasim and S. Saeed (2013). Nitrogen stimulates phonological traits, growth and growing degree days of maize. Pak. J. Agri.Sci, 50(3): 337-344.

Hartman, A. (1988) "Eco physiological aspects of growth and nitrogen fixation in Azospirillium species". Plant Soil, 110: 225-238.

Jackson, W.R. (1993). Organic Soil Conditioning, "Humic, Fulvic and Microbial Balance.

Khan, H.Z., M.A. Malik and M.F. Saleem (2008). Effect of rate and source of organic material on the production potential of spring maize (Zea mays L.). Pak. J. Agric. Sci., 45: 40-43.

Klute, A. (1986). Methods of soil analysis. American Society of Agron., Inc. Soil Sci. Soc. of Amer., Inc. Madison Wisconsin, USA, $2^{\text {nd }}$ Edition .

Lamont, B.B. (2003). Structure, ecology and physiology of root clusters-a review. Plant and Soil. 248: 1-19.

Mahfouze, S.A. and M.A. Sharaf El-din (2007). Effect of mineral vs. bio fertilizer on growth, yield and essential oil content of fennel (Foeniculum vulgare Mill.). Int. Agro. Phys. 21:361-366. 
Marschner, H. (1995). Mineral Nutrition of Higher Plants. 2 nd Ed. Academic Press, Harcourt Brace and Company, Publishers. London, New York, Tokyo, pp 864.

Mikkelsen, R.L. (2005). Humic materials for agriculture. Better Crops, 89 (3): 610.

Nagassa, W., G. Heluf, D. Abdena and E. Geremew (2005). Effect of integrated use of FYM, $\mathbf{N}$ and $\mathbf{P}$ fertilizers on maize in Western Oromia of Ethiopia. Indian J. Fertilizer, 1: 47-53.

Neri, D., E.M. Lodolini, G. Savini, P. Sabbatini, G. Bonanomi and F. Zucconi (2003). Foliar application of humic acids on strawberry (Cv Onda). ISHS Acta Horticulture 594: International Symposium on Foliar Nutrition of Perennial Fruit Plants.

Page, A.I., R.H. Miller and D. R. Keency (1982). Methods of Soil Analysis. Part II. Chemical and Microbiological Methods. 2 ${ }^{\text {nd }}$ Ed. Am. Soc. Agron., Madison, Wisconsin U.S.A.

Parasad, B. (1979). Effect of rates and sources of nitrogen including sulphur coated urea and sulfathiazole treated urea on yield and quality of oat forage Ind. J. Agron., 24: 301-306

Rafla, H. H. (2012). Effect of humic acid and macronutrients on growth, yield and chemical composition of faba bean (vicia faba L.). Egypt. J. Appl. Sci., 27: 927-944.

Salib, M. M. (2002). The integrated effect of humic acid and micronutrients in combination with effective microorganisms on wheat and peanut grown on sandy soil. Zagazig J. Agric. Res., 29:2033-2050.

Sarwar, G. (2005). Use of compost for crop production in Pakistan. Okologie und Umweltsicherung. 26/2005. Universitat Kassel, Fachgabietland schaftso kologie und Naturschutz , Witzenhausen, Germany.
Sarwar, G., N. Hussain, H. Schmeisky and S. Muhammad (2007). Use of compost an environment friendly technology for enhancing rice - wheat production in Pakistan . Pak J. Bot., 39:1553-1558.

Shah, S.A., W. Mohammad, S.M. Shah and M.S. Shafi (2013). Effect of organic and chemical nitrogen fertilizers on grain yield and yield components of wheat and soil fertility. Sci. J. Agron. Plant Breed. 1(2):37-48.

Shah, S.T.H., M.S.I. Zamir, M. Waseem, A. Ali, M. Tahir and W.B. Khalid (2009). Growth and yield response of maize (Zea mays L.) to organic and inorganic sources of nitrogen. Pak. J. Life Social Sci., 7: 108-111.

Singh, M.V., Neeraj Kumar and B. N. Mishra (2013). Integrated use of nitrogen and FYM on yield, nutrient uptake and economics of maize in eastern Uttar Pradesh. Ann.of Plant and Soil Res. 15(2): 128-130.

Singh, S.P., B.L. Gour, Shet and Hawal (1992). Effect of cultivar spacing and nitrogen fertilization on yield and nutrient uptake by maize Annu. Agric. Res., 13: 277-279.

Smith, F., M. Dubois, K.A. Gilles, J. K. Hamilton and L.N. Kebers (1956). Colorimetric methods for determination of sugars and related substances. Anal. Chem., 28:350-354.

Sujatha, M.G., B. S. Lingaraju, Y. B. Palled and K. V. Ashalatha (2008). Importance of integrated nutrient management practices in maize under rainfed condition. Karnataka J. Agric. Sci., 21(3): 334-338.

Varanini, Z. and R. Pinton (1995). Humic substances and plant nutrition. Progress in Botany, (56): 79-117.

Verma, A. and G. S. Tomar (2014). Effect of planting geometry and nitrogen levels on growth, green cob yield, quality and economics of sweet corn (Zea mays saccharata Sturt.). Inter. J. of Agric. Sci. 10: 766-769. 
استجابة نباتات الذرة لمصادر مختلفة من النيتروجين والرش بهيومات البوتاسيوم

\author{
سحر محمد زكريا \\ معهد بحوث الأراضي والمياه و البيئة ـ مركز البحوث الزراعية ـ الجيزة ـ مصر
}

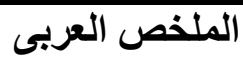

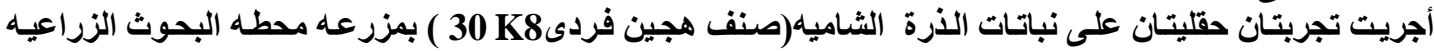

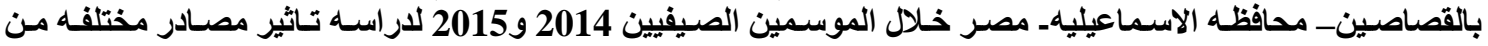

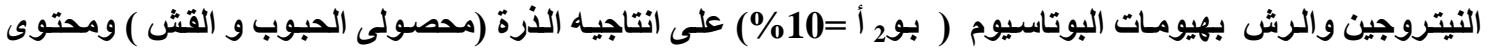

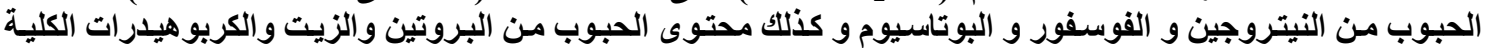
و النشا و السكريات الذائبة الكلية.

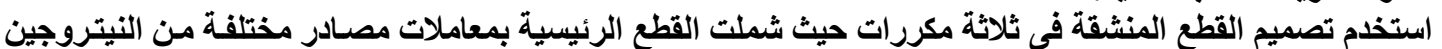

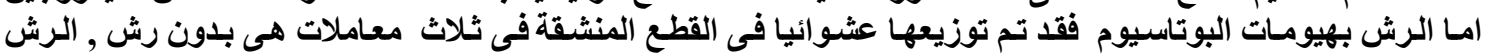

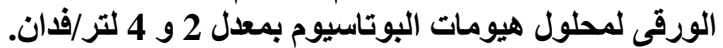

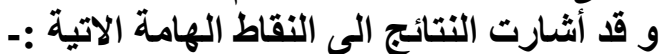

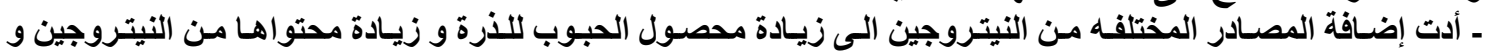

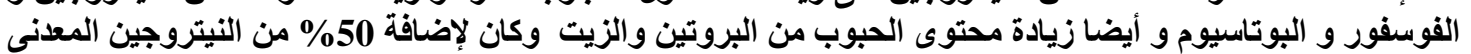

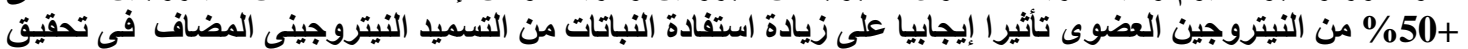

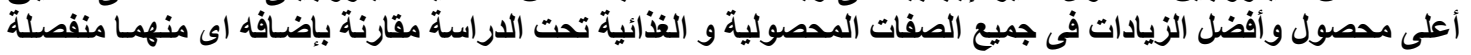

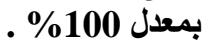

ـ رش هيومات البوتاسيوم أدت الى زيادة محصول الحبوب وأيضا تحسين قيمتها الغذائية و محتوى الحبوب من البروتين.

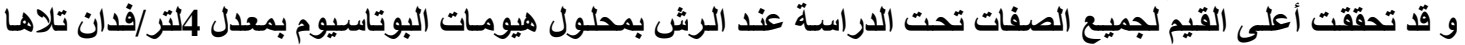

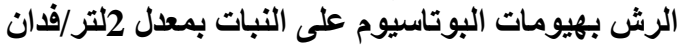

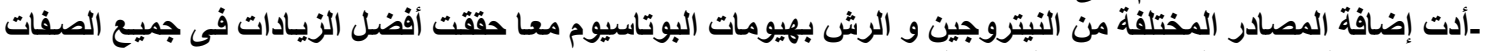

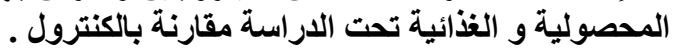

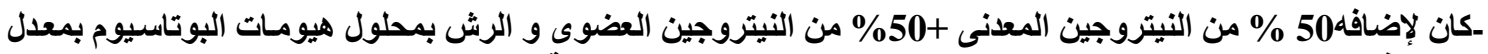

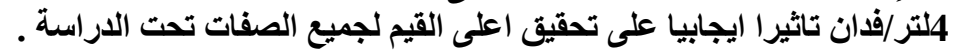

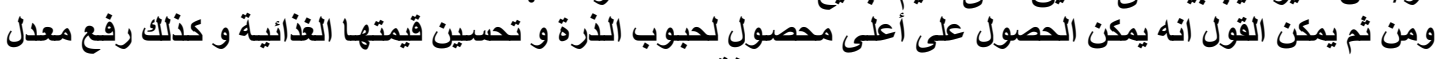

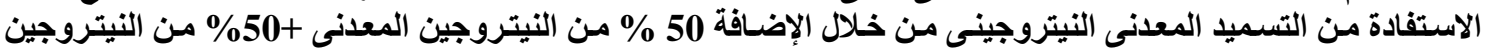

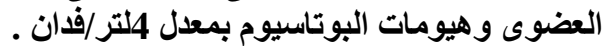

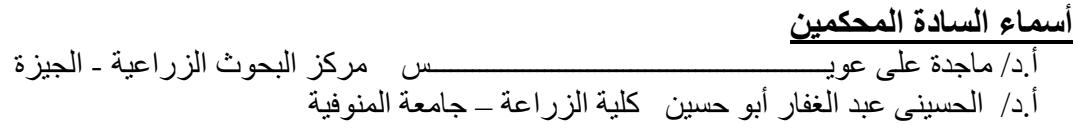

